The Sexual Basis of Racial Formation: Anti-Vice Activism and the Creation of the Twentieth-Century Color Line*

\author{
Brian Donovan \\ Department of Sociology \\ University of Kansas
}

forthcoming in Ethnic and Racial Studies

* Direct correspondence to Brian Donovan, Department of Sociology, University of Kansas, Lawrence KS, 66045. (bdonovan@ku.edu). This research was made possible by a 1998 Dissertation Grant from the Rockefeller Archive Center and a 2000/01 Sexuality Research Fellowship from the Social Science Research Council. The author wishes to thank Wendy Griswold, Orville Lee, Joane Nagel, members of the Northwestern University Culture and Society Workshop, and two anonymous reviewers for their helpful comments. Nicola Beisel deserves special thanks for commenting on several drafts of this article. 


\title{
The Sexual Basis of Racial Formation: Anti-Vice Activism and the Creation of the Twentieth-Century Color Line
}

\author{
Abstract \\ White slavery narratives - stories about white women forced into prostitution - played \\ an important role in the construction of racial distinctions in the early twentieth-century. \\ New York City politicians launched a well-publicized anti-vice crusade in 1910 that led \\ to the imprisonment of a mixed-race woman named Belle Moore. In this article, I \\ analyze this event to show the importance of sexuality and gender for creating racial \\ boundaries. Testimony in People vs. Belle Moore designated certain intimacies as \\ violating the color line, thereby clarifying what it meant to be 'white' or 'colored'. I \\ argue that theories of racial formation must include a more careful consideration of \\ gender and sexuality because the ongoing maintenance of racial categories depends \\ upon cultural narratives about sexual deviance and purity.
}




\section{The Sexual Basis of Racial Formation: Anti-Vice Activism and the Creation of the Twentieth-Century Color Line}

\section{Introduction}

In November 1909, muckraking journalist George Kibbe Turner published a scandalous article in McClure's that accused New York politicians of supporting forced prostitution or 'white slavery'. Two months later, a judge from New York's Court of General Session called for a grand jury to investigate Turner's allegations and appointed John D. Rockefeller Jr. as foreman. Frustrated with the contradictory testimony of the grand jury witnesses, Rockefeller and the District Attorney hired undercover investigators to purchase prostitutes in a sting operation. As a result, police arrested an alleged white slave procurer, a mixed-race woman named Belle Moore. During her trial, the prosecutor characterized Belle Moore as a depraved trafficker in white girls, while her defense attorney assailed the morality of the investigators.

The grand jury investigation and the trial of Belle Moore illustrate how the creation and maintenance of racial boundaries depend upon gendered and sexualized depictions of social actors. In People vs. Belle Moore, attorneys and journalists drew upon sexual stories and stereotypes to characterize the trial participants as threats to, or

protectors of, the 'white' race. This trial represents a general process of racial boundary construction whereby perceived moral distinctions become inseparable from racial ones (Lamont 2000). The discursive fields of sexuality and gender - where humans negotiate the meaning of sexual practices and the definitions of authentic masculinity and femininity - directly shape institutionalized forms of racial inequality. ${ }^{1}$ Organized efforts to curb sexual immorality often embody struggles over social class and the 
reproduction of wealth and privilege (Beisel 1997). Similarly, anti-vice crusaders in the early twentieth-century used dominant ideas about sex and gender to construct durable racial hierarchies.

In this article, I argue that Progressive era (1900-1920) crusades against prostitution played a substantial role in both solidifying a particular twentieth-century understanding of racial whiteness and enforcing segregation based on that worldview. ${ }^{2}$ Omi and Winant (1994) contend that large and small 'racial projects' contribute to the formation of racial hierarchies. I argue that certain racial projects require sex and gender projects because ideas about racial purity define who has sexual access to whom. Stories of sexual danger served as a cultural resource for native-born whites, allowing them to draw sharp racial boundaries. As I will show, white slavery narratives, and the legal action they provoked, contributed to the white-over-black caste system during a time when the meaning and perimeters of whiteness was largely unsettled.

Published accounts of white slavery flourished during the first two decades of the twentieth-century as large numbers of African Americans moved north, and as large numbers of Southern and Eastern European immigrants arrived in U.S. cities. Often mixing fact and fiction, white slavery narratives described the plight of native-born girls forced into a life of prostitution. White slave procurers purportedly ensnared their prey with a variety of methods ranging from brute physical force to false promises of marriage or employment. Typical victims of white slavery were naïve white women from rural locales who traveled to cities in search of love, employment, or adventure. The villains of white slavery narratives variously comprised Italian, Russian, Jewish, Greek, and African American men. The changing ethnic cast of white slave villains 
speaks to the shifting terrain of racial landscapes, boundaries, and meanings during this time. Native-born white Americans attempted to define what it meant to be 'white' and 'colored' through white slavery storytelling and concomitant anti-vice efforts. In what follows, I argue that the regulation of illicit sex in the early twentieth-century played a critical role in establishing the color line, the black/white racial binary that W.E.B. Du Bois ([1903] 1989) famously predicted would dominate twentieth-century America.

\section{Sex and the Color Line}

\section{The Fragmentation and Consolidation of Whiteness}

The racial categories that we now take for granted, particularly the black/white distinction, were contested throughout the nineteenth-century (Allen 1994; Ignatiev 1995; Jacobson 1998; Roediger 1991). 'Whites' did not stand as a monolithic group, but were arranged into a hierarchy of different white races: Anglo-Saxons, Celts, Slavs, Hebrews, Iberics, Nordics, Teutons, Mediterraneans, and others. Although now, in the twenty-first-century, many would regard them as white or Caucasian, members of these groups saw themselves, and were seen as, racially different from other groups of 'whites'. Throughout U.S. history, African Americans were relegated to the bottom of the racial ladder, but the diversity of European immigrants in the nineteenth-century complicated the binary black/white caste system. The racial status of immigrants groups, and the question of whether or not they were 'white', was hotly contested in discussions about politics, immigration, and labor.

Since the eighteenth-century, 'white' and 'colored' racial categories were consistently defined in opposition to one another (Fredrickson 1971; Jordan 1974), but membership within those categories shifted in the years leading up to World War I. 
During the 1920s, the category 'Caucasian' emerged to absorb groups that were previously considered racially distinct, making the Italians, Jews, and Irish 'white,' and making the demarcation between 'colored' and 'white' more absolute. ${ }^{3}$ The broader category of Caucasian emerged during the first two decades of the twentieth-century in response to a host of demographic and political factors, including the first wave of African Americans migrating to Northern cities from 1900 to 1930. The whitening of different immigrant groups such as the Italians and the Irish created a stark dichotomy between the categories 'colored' and 'white'. Jacobson (1998, pp. 110-111) argues that during the 1920s 'A complex system of races had given way to a strict scheme of black and white, which itself implied an absence of race on the white side and a presence of race on the black'. New anti-miscegenation laws, immigration restrictions, and heightened residential segregation accompanied these changes in racial thinking (Davis 1991; Lopez 1998).

\section{Sex, Gender, and the Cultural Creation of Racial Boundaries}

In attempting to account for historical changes in racial categories, scholars have called attention to the 'structural' basis of racial taxonomies, highlighting the enduring and institutionalized aspects of otherwise arbitrary systems of difference. A dominant thread in the scholarship on race considers race in structural terms, both as a structure itself (Bonilla-Silva 1997) and as a product of social structural change, such as shifting labor markets, immigration patterns, and the unequal possession of socio-economic power (Allen 1994; Ignatiev 1994; Roediger 1991, 1994). In an attempt to find a materialist cause of racial categorizing, structuralist accounts tend to reduce racial 
formation to class formation (Allen 1994; Ignatiev 1994; Roediger 1991) or to a semiautonomous racial ‘system’ (Bonilla-Silva 1997).

These perspectives offer an indispensable, yet limited, account of racial formation. Moral distinctions are an essential component of objective boundaries between socially stratified groups (Lamont 2000). People perceive material differences in symbolic terms and, in turn, these distinctions help perpetuate material inequality. Thus, the creation of racial boundaries includes a powerful cultural dimension that is intimately connected to social structural forces (Lamont 1999, pp. ix-xii). A historical examination of how people culturally respond to large-scale social change moves us toward conceptualizing race as a boundary-making practice instead of viewing it as an inevitable outcome of structural dynamics. The approach offered here interrogates how people create, defend, and close ranks around their classifications; it explores the historical and cultural process of 'group-making' (Loveman 1999; Wacquant 1997).

The boundaries that demarcate racial groups depend upon ideologies that justify segregation, interracial sexual prohibitions, and other forms of social separation. Scientific theories of race that developed in the nineteenth-century gave racial categories a powerful foundation by invoking the authority of scientific truth. In the nineteenth-century, ideologies of blood purity shaped new forms of racial thinking (Foucault 1984; Stoler 1995). Racial ideologies upheld the supposed naturalness of race based on ideas of lineage and descent; we belong to a particular race if only because our parents belong to that race. In this way, racial categories relied upon an image of the family as a unit of racial belonging. Struggles for 'racial purity' exemplify the boundary work required of racial formation. To maintain racial boundaries, racial formations mobilize ideologies of gender, sexuality, and reproduction - deeming racial 
outsiders as sexually dangerous and racial insiders as racially restorative. While the mythical bond between race and blood gave racial formations new authority and power, it also made them vulnerable to different sexual and gendered practices.

Constructing categories understood as 'racial' requires regulating sexual intimacy within and between groups. The management of women's sexuality is particularly important for making racial categories because women can create babies and 'bloodlines' that others see as an expression of racial purity or impurity (Liu 1994; Stoler 1995, 1989). Scholarship on race must carefully consider the intersection of race, gender, and sexuality because racial group-making depends upon specific ideas about who men and women can associate with, have sex with, and produce children with. Sexual identities and practices form a 'substructure' of social life that helps define and reinforce racial hierarchies and regimes (Nagel 2000).

Efforts to control inter-racial association are built upon race-based stereotypes of sexual desire and proclivity. Narratives of sexual perversity and danger clarify the boundaries of racial groups, allowing people to speak of a collective 'us' as opposed to a 'them'. Sexualized representations of outsiders not only give a symbolic basis for group identity, but they provide a rationale for inter-group violence and coercive social separation. For example, stories about animalistic black men raping white women provided a rhetorically powerful justification for lynching in the post-Reconstruction South (Bederman 1995; Ferber 1998, pp. 34-40; Hale 1998; Hall 1983; Hodes 1992). Although the idea that African American men were unable to control their sexual desires was a staple of white racial thinking throughout the nineteenth-century (Jordan 1974), the myth of the 'black beast rapist' gained wide acceptance only in the late 1880s, reflecting the political insecurity of Southern whites after Reconstruction (Hall 
1983; Hodes 1992). Bederman (1995, p. 46) notes that 'as the myth of the Negro rapist spread throughout the South, the incidence of Southern lynching soared'. ${ }^{4}$ Although most African American lynching victims were not accused of rape, it remained the South's primary justification for the practice (Davis 1991, p. 53).

White Northerners did not borrow the Southern narrative of the black rapist, but they disseminated their own story of sexual danger that drew upon the memory of abolitionism; they claimed to have discovered a new form of slavery. As the African American population in New York City rapidly grew, ${ }^{5}$ the white slavery narrative helped shape the city's racial landscape. The remainder of this article will analyze a criminal trial to show how white New Yorkers responded to the Great Migration legally and culturally. As fears about white girls sold into sexual slavery swept U.S. cities, New York politicians launched a grand jury investigation into commercialized prostitution. Their inquiry resulted in the arrest of a Jewish man, and the wellpublicized trial of a 'mulatto' woman. New York City's anti-vice crusade of 1910 helped cement the color line by providing an uniquely Northern justification for segregation, helping to shore up a dichotomous understanding of 'whites' and 'coloreds'. These efforts in the name of sexual purity and morality provide a window into the racist reaction to African Americans migrating North and the gradual whitening of immigrants living in North American cities.

\section{The Racial Politics of Prostitution in New York City}

Reform organizations produced and distributed books and pamphlets about white slavery as early as the $1880 \mathrm{~s}$, but journalists popularized the issue decades later with widely read magazine articles. Journalist George Kibbe Turner published several 
accounts of white slavery that stirred public debate in New York City and Chicago. Turner's 1909 article in McClure's, 'The Daughters of the Poor: A Plain Story of the Development of New York City as a Leading Center of the White Slave Trade of the World, Under Tammany Hall', accused immigrant politicians of aiding pimps and procurers in their nefarious business. His article had an immediate impact on political life in New York City. ${ }^{6}$ Turner (1909, p. 61) closed his article with a question and recommendation: 'Shall New York City continue to be the recruiting-ground for the collection for market of young women by politically organized procurers? The only practical way to stop it will be by the defeat of Tammany Hall'.

With its reputation under attack, Tammany Hall had to disprove its connection to the vice trade or at least gesture toward a solution. Two months after the publication of Turner's 'Daughters of the Poor', Tammany supporter Judge Thomas O’Sullivan commissioned a grand jury to investigate prostitution in New York City. Confronted with weak evidence of organized white slavery, District Attorney Charles Whitman (who had been elected on an anti-Tammany ticket) and Assistant District Attorney James Reynolds commissioned two undercover investigators to purchase prostitutes in a sting operation. $^{7}$ They hired George Miller, an investigator from the Anti-Saloon League and the Immigration Commission; and Frances Foster, a child welfare worker from Boston.

Investigator George Miller posed as an Alaskan brothel owner who hoped to establish a new house in Seattle. Much of his investigative work occurred in New York City's Tenderloin district in 'black and tans' saloons that catered to African Americans and whites. Miller established a rapport with members of New York's interracial sex trade and eventually purchased four prostitutes after weeks of negotiations. He bought 
two Jewish girls for forty dollars from a Russian Jew named Harry Levinson and two white girls for $\$ 120$ dollars from a woman named Belle Moore. Levinson pleaded guilty and offered to help the District Attorney in exchange for a lenient sentence. ${ }^{8}$ Discussion of these events reverberated throughout New York City. In fact, a local newspaper reported that a businessman named Harry Levinson legally changed his name because of the flood of angry letters he had received from strangers, colleagues, and relatives due to the press reports of his namesake (Evening Mail May 12, 1910, p. 2). Yet attention to Levinson waned in early May, and the District Attorney's office directed their focus to Belle Moore, the woman accused of selling white children into a life of prostitution.

The District Attorney's office charged Belle Moore with the compulsory prostitution of women. ${ }^{9}$ The jury found her guilty, and the judge sentenced her to the maximum term allowed by the statute: five years in prison. During the trial, attorneys and journalists attempted to characterize Belle Moore, the investigators, and the victims as either promoting or damaging the integrity of the 'white' race. As I will show, the attorneys used an interlocking discourse of gender, sexuality, and race: they attacked or lauded the manhood or womanhood of their witnesses by assessing their willingness to cross the color line. Likewise, they portrayed their witnesses as race traitors or race exemplars by mobilizing hegemonic notions of masculinity and femininity. Newspaper accounts of the trial amplified these representations. Journalists and attorneys reinforced a particular understanding of whiteness and blackness by articulating, with varying degrees of success, four types of sexual actors: the white slave, the white slave procurer, the New Woman, and the bohemian. 


\section{White Slaves and Racial Purity}

The Rockefeller inquiry intended to uncover evidence of white women forced into prostitution. Investigator George Miller testified that during his first meeting with Belle Moore he told her 'I don't want colored girls. I want white girls, girls weighing less than one hundred pounds, not more than one hundred ten at most, must be naturally good looking, well built and be able to get twenty or twenty-five dollars in any whorehouse' (People v. Belle Moore [hereafter 'Moore'] 1910, p. 9). During Miller's second meeting with Belle Moore, another investigator named Frances Foster accompanied him and posed as the prospective manager of his new brothel in Seattle. She reiterated Miller's request for racially pure girls. Foster testified: 'I did not want a girl that showed any stain of colored blood, because I was afraid to put her in my house with white girls. I said that colored girls would not do' (Moore 1910, p. 143).

The construction of white womanhood in the white slavery narrative linked racial and sexual purity. Accordingly, investigators also sought - not only 'white' as opposed to 'colored' girls - but sexually innocent girls. After the arrest of Belle Moore, Assistant District Attorney James Reynolds consistently tried to portray the girls she reportedly procured as virtuous children. When discussing the case with the New York Times, he described one girl as 'so little and so childish that she wept when they took her from one house to another because she had to leave her Teddy bear behind' (New York Times April 30, 1910, p. 1). The article continued:

It was Belle Moore, Mr. Reynolds explained, who sold the other two girls. They gave their ages as 17 and 18, but even Belle Moore says they are younger. It is understood that they are only 15 . And these are white girls. It was one of them who was so disconsolate over the loss of her Teddy bear. The other whom the purchase freed from a house where she had been kept ever since last September, brought 
nothing with her except a tattered doll, which she still cherished. It was dearer to her than anything else in all her unlovely world (New York Times April 30, 1910, p. 1).

During the trial, Reynolds continued to pepper his description of the victims with 'anecdotes of the wept-for Teddy bear and the cherished "dolly"' (New York Times April 20, 1910, p. 18). The Times emphasis that 'these are white girls' placed them in a racial category for their readers, but the report did not locate the victims within the nineteenth-century constellation of white races, nor did it refer to them as 'Anglo-Saxon girls'. The press report did not need to specify their whiteness because it implicitly defined them against the 'colored' prostitutes that populated New York City's Tenderloin district. The use of these terms reflected and contributed to an increasingly dichotomous understanding of racial categories.

The facts revealed during the trial did not substantiate the District Attorney's claim that Moore trafficked in innocent girls. In fact, the two 'girls' that Moore sold to undercover investigators were experienced prostitutes over the age of twenty. At the trial, the alleged victims shocked courtroom observers with their age and demeanor. Alice Milton 'confessed to 23, and looked the part, despite a cluster of brown curls, which she carefully arranged on either shoulder as she entered the room' (New York Times May 5, 1910, p. 6). She wore a 'mammoth scarlet hat, and throughout her testimony swung a patent-leather toe in the neighborhood of the stenographer's left ear' (New York Times May 5, 1910, p. 6). The other woman, Belle Woods, was twenty-five and previously married. She testified that Miller and Moore discussed the plan with her and Milton, and that Miller offered both women money to move to Seattle. Woods said 'All I remember is he asked us to go to Seattle, made arrangements for us to go to Seattle, and I said "Yes, I would go"' (Moore 1910, p. 239). 
Perhaps anticipating the public's inevitable discovery that he greatly exaggerated the victims' sexual innocence, District Attorney Reynolds suggested that Belle Moore abducted and attempted to sell to the investigators an eleven year-old girl named Helen Hastings. The New York Daily Tribune described Hastings: 'She is white, not more than eleven years old, about 4 feet 6 inches in height, with short, curly brown hair, dark blue eyes and good teeth' (New York Daily Tribune May 4, 1910, p. 1). When police failed to find the eleven year-old girl after conducting a thorough search, the District Attorney insinuated that she was a victim of foul play. Yet, newspaper accounts suggested that prosecutors fabricated their story of the blue-eyed Helen Hastings. The Evening World interviewed the residents in Moore's apartment complex and reported that 'all are quite positive Belle Moore never had a little white girl in her flat' (The Evening World May 4, 1910, p. 4). One resident said 'I'm sure she wouldn't bring a white girl here. She couldn't do it and escape detection' (The Evening World May 4, 1910, p. 4).

The District Attorney's descriptions of Alice Milton, Belle Woods, and Helen Hastings connected white racial purity with childhood innocence. Although Alice Milton and Belle Woods were not sexually naïve children, the District Attorney's persistence in characterizing them as white slaves suggests the cultural power of this narrative and the bond between racial and sexual purity it invokes. The white slave victims Reynolds described did not have sexual desires that would lead them to associate with people outside of their racial category; they upheld racial purity with their sexual innocence.

The purported white slaves also physically embodied racial purity. Frances Foster deployed the logic of the 'one-drop rule' when she refused to purchase girls who 
showed 'any stain of colored blood'. This understanding of race marks a person with any African ancestry as 'colored,' 'black', or 'mulatto', and places them firmly outside the categories of 'Anglo-Saxon', 'white', and 'Caucasian'. Anti-miscegenation statues and court decisions gave legal weight to dominant notions of white racial purity (Lopez 1998). The one-drop rule has a long and complicated history stretching back to the 1700 s, but as the next section will show, white Northerners invested it with new intensity in the early twentieth-century.

\section{Femininity, Masculinity, and Racial Transgression}

\section{Belle Moore, the Mulatto Procuress}

According to the prosecution and the press, Belle Moore viciously undermined the social division between 'white' and 'colored' persons by corrupting 'white' girls. The Evening Post described her as 'a so-called black-and-tan procurer, who was holding and selling white girls for the use of both colored and white men' (The Evening Post April 30, 1910, p. 4). The press and trial attorneys variously referred to her as a 'mulatto,' a 'negro', a 'negress', and 'colored'. The interchangeable terms used to describe Moore signal a growing notion of monolithic blackness. In the nineteenthcentury, the term 'colored' exclusively referred to mulattos, but eventually came to refer to anyone with African ancestry (Davis 1991, p. 6).

Representations of Moore reflected and promoted a historical shift in racial thinking. Moore, whether a 'mulatto,' 'negress,' or 'colored,' became part of an overarching group implicitly defined against 'white'. Despite reports of her light skin, descriptions of Moore did not insist on her mulatto status as somehow different from 'negro' or 'colored'. This acceptance of the one-drop rule differed from dominant 
understandings of race that had prevailed for much of the prior century. Whites in the nineteenth-century debated the qualities shared by mulattos. Some Northern abolitionists portrayed mulattos as a 'superior human type' whose mixed blood took 'the rough edges off the overly aggressive Anglo-Saxon' (Fredrickson 1971, p. 121). Others argued that this mixture made them restive and rebellious. Although debates about 'amalgamation' lingered in the twentieth-century, the category of 'colored' absorbed mulattos as the distinction between African Americans and whites sharpened. As opportunities for association between African Americans and whites flourished in Northern cities, the mulatto moved from a symbolic figure - whose characteristics whites could discuss in the abstract - to a living threat to white identity by their ability to 'pass' as white.

Belle Moore demonstrated some ability to 'pass', albeit symbolically, in her dealings with the investigators. While discussing the price of the prostitutes, Foster assured Moore that she would pay her well. According to Foster, Moore said that 'she wasn't worried about money, and that she knew I would treat her white' (Moore 1910, p. 145). Foster promised to regard Moore as 'white' by dealing with her as an economic equal. Moore's lighter skin color perhaps conferred privileges not shared by those with darker skin. Lighter skin African Americans have consistently enjoyed social, political, and economic advantages that are denied to those with darker skin tones, creating an internal stratification system within the racial category (Russell et. al. 1992). Although Moore may have benefited from colorism in the interracial sex trade, newspapers alluded to the diminished social distance between Moore and white New Yorkers, and insinuated that her social status allowed her to become a sexual/racial threat. In this sense, Moore personified an aggressive version of the 'tragic mulatto', a 
popular nineteenth-century literary figure caught between two racial worlds and at home in neither (Bentley 1993).

The New York Times described Moore as 'an extremely light mulatto' who 'had a rather gayly furnished apartment at 348 West Forty-first Street' (New York Times May 5, 1910, p. 20). Another report added that Belle Moore is 'probably not more than 35, with a thin, rather acrid face. She has an appearance of great intelligence, and is not unsuggestive of Cassie [sic] in “Uncle Tom's Cabin"” (New York Times May 19, 1910, p. 5). The comparison to the mulatto character Cassy places the crusade against white slavery within the history of Northern abolitionism, although it transposes its victims and villains. Cassy experienced sexual exploitation in Uncle Tom's Cabin. The slave master Simon Legree sold her children and forced her into sexual servitude. ${ }^{10}$ In white slavery narratives with African American villains, freedom from bondage in the South allowed African Americans to enslave white women in the North. The Evening World upheld this rhetorical inversion when they described Moore as 'the negro alleged slave trader' (Evening World May 6, 1910, p. 4). During the nineteenth-century, white abolitionists portrayed African Americans as naturally submissive, affectionate, and loyal. This ideology of 'romantic racialism' found its clearest expression in Uncle Tom's Cabin (Fredrickson 1971, pp. 110-125). By 1910, this novel provided a touchstone to discuss white slavery, and its new use reflected a change in how Northern whites comprehended racial difference.

Finally, prosecutors used another stereotype of African American women to characterize Belle Moore: the sexually licentious Jezebel. ${ }^{11}$ The Jezebel image depicts black women as lusty seducers (Collins 1990; Jewell 1993). During his testimony, investigator George Miller described a meeting with Moore where young 'colored' men 
and women played music while everyone danced and drank together until 3:30 in the morning. Miller testified that Moore entertained the group 'by dancing with her skirts up over her knees and higher' (Moore 1910, p. 14). Yet the willingness of the investigators to drink and dance with 'colored' people gave Belle Moore's defense attorney an obvious courtroom strategy.

\section{Frances Foster, the New Woman}

Defense attorney Alexander Karlin tried to malign the investigators by portraying their behavior as a betrayal of the white race, and newspaper accounts reaffirmed his accusations. In so doing, claims-makers inside and outside the courtroom helped articulate a sexual criterion for being 'white.' Karlin tried to characterize Frances Foster, the thirty-two year-old investigator, as a New Woman. According to Smith-Rosenberg (1985, p. 178) the rise of the New Woman 'more than any other phenomenon of the 1910s and 1920s, signaled the birth of a new era'. New Women were highly educated, independent, and much more sexually assertive than earlier generations of women. Many eschewed marriage and motherhood in order to pursue other forms of self-definition (Stone and McKee 1999, pp. 48-50). While New Women reflected a real shift in women's opportunities and lifestyles, they also stood as a caricature in public discourse. Belle Moore's defense attorney had little difficulty typifying Frances Foster as a New Woman in front of the all-male jury.

Over the objections of the prosecuting attorney, Alexander Karlin succeeded in eliciting several details about Frances Foster's life. Foster reluctantly admitted during cross examination that she was married, but had no contact with her husband for the last ten years, and had no children. The prosecuting attorney objected when Karlin asked 
'Are you a graduate of any college'? but the judge allowed the question to stand, and Foster replied that she graduated from Radcliffe. Karlin questioned Foster about her prior employment and discovered that she did child protective work for a Boston charity organization. The answers to Karlin's follow-up questions demonstrated that Foster continued working after marrying her husband - a fact that she seemed reluctant to disclose (Moore 1910, pp. 156-60).

Next, Belle Moore's defense attorney tried to establish that Frances Foster developed a close and improper relationship with Belle Moore. He asked 'From the time that you first met this defendant, under what name had you been in the habit of addressing her? A: Addressing her as Miss Belle Moore. Q: Oh, so you got so intimate with this colored procuress that you called her Belle'? (Moore 1910, p. 178). Karlin suggested that Foster did not maintain the proper distance from her target. By referring to his client as a 'colored procuress', Karlin briefly conceded Belle Moore's crimes in order to charge Foster with violating the color line. He suggested to the jury that they should concentrate on Foster's impropriety as a white woman instead of Moore's procuring.

Karlin tried to argue that Foster violated the color line by 'slumming' in racially mixed saloons and cafes. Although many members of New York's upper and middleclasses visited the vice districts, it was largely a male form of recreation. ${ }^{12}$ Karlin repeatedly mentioned that Foster visited 'colored folks' in black and tan saloons to cast doubt on her morality as a white woman. Karlin asked 'Do you think it is just the kind of work for a college graduate to be engaged in, to go around negro resorts to get evidence'? (Moore 1910, p. 160). Karlin questioned Foster about her visits to black and tans in order to give the jury a concrete image of her transgressions: 
Karlin: These cafes as I understand, they are frequented by colored folks, and they have tables where drinks are served and Orchestras play certain kinds of music. Foster: Colored folks only, do you mean?

Q: No, among others, colored folks go in there? A: Yes.

Q: And the proprietors of these institutions are colored folks? A: Yes.

Q: And drinks are served at the tables? A: Yes.

Q: And you, a college graduate of Radcliffe College were hanging out with the colored folks of those places? A: We did (Moore 1910, pp. 163-164).

Karlin emphasized that Foster, working under the persona of 'Frankie Fuller', did not simply observe the drinking and revelry, but she actively enjoyed it. The New York Times echoed Karlin's accusations when they described 'the weeks she spent in the Tenderloin, sometimes staying for hours at a stretch in restaurants, with colored men and women drinking at her elbow' (New York Times April 20, 1910, p. 18). Karlin's cross-examination of Frances Foster and press reports of the trial focused on the incongruity of her prestigious education and the apparent ease with which she crossed racial boundaries.

That a college-educated woman involved herself in this line of work captivated news writers, and we can infer that it fascinated their readers as well. The New York Times reported that 'There was a great stir in the courtroom yesterday morning, when the prosecution called as its second witness 'Mme. Fuller', in the person of Mrs. Frances Foster, a Radcliffe college graduate of some years ago' (New York Times May 20, 1910, p. 18). The Evening Post often referred to her as 'the college woman'. The New York Daily Tribune titled her the 'Radcliffe College girl' and described her as 'a fashionably dressed young woman with eyeglasses' (New York Daily Tribune May 19, 1910, p. 1). The Evening World termed her 'the college graduate sleuth' and published 
her photograph under the headline "College Woman Who Helped To Set "White Slave" Traps' (Evening World May 19, 1910, pp. 1-2).

Belle Moore's defense attorney suggested that Foster's duties as a white woman superseded her duties as an investigator. Likewise, elite commentators often blamed women's colleges for leading white women graduates to shirk their racial responsibilities by having only a small number of children or none at all (Bederman 1995; May 1995). In 1911, approximately half of the graduates of women's colleges remained single (May 1995, p. 64). The New Woman challenged male privilege and the Victorian sexual order (Smith-Rosenberg 1985; Stone and McKee 1999), but she also posed a racial threat. Women's new freedoms and the national interest in white slavery coincided with sweeping fears of 'race suicide' caused by falling birth rates among native-born whites. Concerns that immigrants would out-breed whites prompted a national discussion that celebrated white male virility and white female fertility (Bederman 1995). The issue of race suicide shows how sexual and racial projects that intersect at the level of public discourse offer a cultural resource that can be used in specific contexts, like a criminal trial. Karlin could ask Foster about her visits to black and tans without explicitly stating why these visits should offend the jurors. Karlin invoked a powerful configuration of images that tied white women's freedoms to racial vulnerability.

\section{George Miller, the Bohemian}

Although racial projects often focus on women's sexuality, cultural understandings of race and masculinity shape and constrain men's practices as well. Reports of race suicide enjoined white men to act on their sexual desires exclusively 
with their white wives, but urbanization and changing norms of masculinity prompted them to explore other forms of sexual expression. During the Progressive era, a tougher and more body-centered ideal of middle-class white manliness slowly replaced the Victorian model of the sensitive and character-centered man (Bederman 1995; Kimmel 1996). The practice of slumming and the emerging bohemian and bachelor subcultures in large urban centers defied the Victorian notion of masculine self-restraint. Also, subcultures of men who had sex with other men were a highly visible presence in turnof-the-century New York City (Chauncey 1994). Gay men found acceptance in Harlem's black/white vice districts and often socialized in black and tan saloons (Mumford 1996).

Like his colleague Frances Foster, George Miller's investigative work in interracial saloons exposed him to charges of sexual and racial impropriety. George Miller began living at the Hotel Albany under the name of 'Dick Morris'. He tried to create an image that he was a wealthy bachelor looking for a good time in New York City and he worked to befriend Steve, an African American doorman at the hotel. Miller told him that he would like to see various cafes and saloons, and asked Steve to show him around the city. Miller eventually found Belle Moore after making the acquaintance of several black and tan habitués. Alexander Karlin, Belle Moore's defense attorney, mobilized mutually constitutive ideas about white masculinity and racial segregation to throw doubt on the prosecutor's star witness. Karlin charged investigator George Miller with an array of deviant acts, from sharing a bed with a black man to having sex with a white girl.

Belle Moore's defense attorney attacked George Miller for his frequent association with African Americans during his investigative work. Karlin used this 
strategy both to cast doubt on Miller's manhood and assert his traitorous action toward the white race. Miller had to adopt a certain persona to gain the confidence of his targets, but Karlin argued that Miller's behavior was more than a mere act. Karlin suggested to the jury that Miller took excessive pleasure in associating with underworld contacts. During cross-examination, Karlin forced him to admit that he drank with an African American waiter at the cafe.

Karlin: And you stopped at Baron Wilkins' [café] that evening about how long? Miller: About an hour, half and hour, I am not sure.

Q: Drinking with this colored man? A: Yes, sir.

Q: You bought champagne, didn't you? A: Not that night.

Q: Did you some other night? You bought champagne pretty liberally? A: Yes, sir. Q: Well, you drank a great deal. About how many drinks did you have with this colored man, Alex Anderson on the night of the 13th? (Moore 1910, p. 39)

He used the same rhetorical strategy by persistently mentioning Miller's interest in 'colored resorts'.

Karlin: Didn't you tell Steve sometime in the month of April that you were here from Seattle to have a good time, that you would like to see the various colored resorts in New York and asked him to show you around? A: Yes, sir.

Q: And hadn't Steve refused several times to take this sport from the Hotel Albany around to the different colored resorts? A: No, sir.

Q: How many times did you talk to Steve before he finally took you to any colored resorts? (Moore 1910, p. 37)

Karlin suggested that Steve persistently declined Miller's request to take him to black and tan saloons in order to emphasize that the colored doorman, not the white investigator, respected the color line.

Next, Karlin added sexual impropriety to his charge against Miller by accusing him of sharing a bed with African American men and women. Although he probably 
anticipated Miller's denial, Karlin raised the possibility of misconduct in the minds of the jurors. Karlin promised to prove 'beyond a reasonable doubt that George Miller had slept with her [Moore] and had slept with another female, and slept with a colored man by the name of Alex Anderson on April 13th' (Moore 1910, p. 233). He initially made these accusations when cross-examining Miller:

Karlin: Upon your oath, Mr. Miller, will you kindly answer this question. Didn't you on the morning of the first day that you were in the apartment of this defendant occupy the same bed, first with Alex Anderson, second with Belle Moore the defendant, and third with another colored girl? Upon your oath, tell me if that is not so, Mr. Miller? A: No, sir (Moore 1910, p. 49)

Karlin charged Miller with sharing an intimate space with an African American man to suggest racial and sexual transgression. The insinuation of homosexual activity, although incriminating, did not completely rebuke Miller's masculinity. Men in the early twentieth-century could have sex with other men without damaging their masculinity or heterosexual status, as long as they acted characteristically masculine and assumed the insertive role in sex acts (Chauncey 1994). Moreover, black men typically adopted a stereotypically feminine role in interracial same-sex practices (Mumford 1996, p. 400). Yet homosexual activity in the back and tans violated the color line, and commentators condemned it with the same language they used to describe interracial heterosexual relationships, as 'miscegenation' (Mumford 1996, p. 399). Karlin depicted Miller as sexually degenerate, willing to associate with nonwhites to satiate his sexual desires.

Making his most grievous accusation, Karlin implied that Miller had sex with the eleven year-old Helen Hastings at Belle Moore's apartment. Karlin argued that Miller lied about his whereabouts to cover up his sexual escapades. After his first 
meeting with Moore, Miller claimed that he left her apartment, went to a bar, visited a cigar stand, and then took a long walk before returning to his hotel. Under direct examination, Miller testified that, 'Belle Moore and I and the white girl went into the first bedroom. There she ordered the girl to disrobe and exposed her to me and asked me if I would stay the night. I excused myself and said "No"" (Moore 1910, p. 10). Karlin took these details and raised the possibility of another, less honorable, scenario involving Miller and the young girl:

Karlin: She ordered somebody to disrobe? Miller: Yes, sir

Q: In your presence? A: Yes, sir

Q: And disrobe for you? A: Yes, sir

Q: And she told that to whom? A: Helen Hastings.

Q: Helen Hastings? A: Yes, sir

Q: Did you refuse to have any sexual intercourse with this girl? A: Yes, sir

Q: I took it that you were quite shocked at the indecent proposal made to you? [objected to - sustained]

Q: Well, as a matter of fact, you declined to do any such thing, is that so?

Judge: He answered he did not.

Karlin: Well, you declined to do so, because of your conscientious scruples as a married man? [objected to - sustained] (Moore 1910, p. 56)

The culmination of Karlin's accusations effectively marked Miller as a 'tramp bohemian', a marginal figure in the Progressive era's hierarchy of masculine styles that glorified the underworld and sexual irresponsibility (White 1993, pp. 39-50). The apparent primitivism and sexual spontaneity of African American culture influenced this conception of white manliness, and at the same time provided an example against which bearers of more legitimate forms of masculinity could define themselves. Bederman $(1995$, p. 4) argues that during the transition from the nineteenth to the twentieth-century, 'Americans were obsessed with the connection between manhood 
and racial dominance.' Restraint, self-mastery, and appeals to 'civilization' underscored dominant conceptions of middle-class white manliness. ${ }^{13}$ The attempts of bohemians to enjoy the perceived vitality of African American culture blurred racial boundaries. The accusations that Miller enjoyed the debauchery that he was supposedly investigating show how constructions of race (stereotypes of African Americans as primitive, over-sexed, and savage) shaped dominant notions of white masculinity.

The creation of the twentieth-century color line depended upon stereotypes, or 'controlling images', (Collins 1990) of African Americans, but images of white sexuality were also used to enforce racial distinctions. Just as narratives of black rapists and the threat of lynching communicated a double message to both black men and white women (Hall 1983), the white slavery narrative worked to police the sexual practices of both racial insiders and outsiders. White women who navigated New York City's underworld and white men who slept with white slaves provided negative examples that helped to define the boundaries of whiteness. Frances Foster and George Miller may have tried to protect white girls by investigating the vice trade, but Belle Moore's defense attorney easily depicted their inquiry as a grave violation of the color line.

\section{Conclusion}

Contemporary understandings of racial categories often prevent us from comprehending what was at stake in previous eras. The color line between African Americans and whites permeated twentieth-century America, but as Jacobson (1998, p. 7) observes, 'between the 1840s and the 1920s it was not altogether clear just where that line ultimately would be drawn'. The language used to discuss and explain white slavery reflected and contributed to different ways of thinking about race in the first two 
decades of the twentieth-century. 'Mulattos', however light their skin tone, became interchangeable with 'coloreds' or 'negroes'. Newspapers could report that the vice investigators in the Belle Moore case "visited a number of cafes and resorts frequented by persons of both races', (Evening World May 19, 1910, p. 1) and assume that readers knew to which races they referred. During the trial of Belle Moore, attorneys and journalists used the dichotomy of 'white/colored' that the South developed decades earlier to designate Jim Crow cars, drinking fountains, and bathrooms. In this way, anti-vice crusades launched by urban Progressives intensified and provided a rationale for de facto segregation in the North. ${ }^{14}$

The trial against Belle Moore foreshadowed legal efforts to police interracial sex in the name of a nation-wide war on vice. Less than two months after People vs. Belle Moore, Congress passed the Mann White Slave Traffic Act authored by Illinois senator James Mann. Although supposedly a law against forced prostitution, prosecutors used the Mann Act to punish African Americans and whites for consensual sex (Langum 1994; Mumford 1997). In one of the most well known applications of the Act, the FBI charged heavyweight champion Jack Johnson with violating the Mann Act for crossing state lines with a white prostitute. ${ }^{15}$

I have argued that native-born whites in the United States used narratives of sexual deviance to create and solidify racial distinctions. The creation of the twentiethcentury color line depended upon images of sexual depravity and innocence because the categories 'colored' and 'white' embodied sexual meaning and membership criteria. Scholarship on race must include a more careful consideration of gender and sexuality because racial group-making entails prescriptions and proscriptions about different forms of intimacy. During the trial of Belle Moore, both the defense and prosecutor 
accused their opponents of sexual deviance to make claims about racial boundaries and the importance of segregation. Although crusades against white slavery seem to stand at the margins of American history, they were central to the cultural construction of racial difference. 


\section{Notes}

${ }^{1}$ In making the case that sexual and gendered practices form a fundamental basis for racial formation, I often use the terms 'gender' and 'sexuality' together. Notions of proper sexual expression mobilize cultural norms of masculinity and femininity. In turn, hegemonic understandings of masculinity and femininity depend upon heteronormative ideas of female and male conduct. For analyses of changes in gender identity and sexuality in U.S. history see Bederman (1995), Chauncey (1994), and Kimmell (1996).

${ }^{2}$ In this article, I sometimes use the term 'colored' when discussing the classification scheme used by North Americans in the early twentieth-century to refer to Americans of at least partial African descent. Otherwise, I use the term 'African American' to refer to Americans of African descent. The changing use and meanings of the terms 'black', 'mulatto', and 'colored' will be addressed later in this article. For a discussion of the shifting terminology used to describe African Americans, see Davis (1991). For a defense of the term 'African American' in contemporary writings about race, see Patterson (1998, pp. xxi-xxii). For thoughtful observations about the academic practice of setting racial terms in quotation marks, and the epistemological implication of those practices, see Jacobson (1998, pp. ix-x).

3 See Jacobson (1998). The whitening process for different immigrants groups occurred unevenly. For instance, many native-born whites in the United States viewed Jews as distinct from authentic whites until the 1950s and 60s. See Brodkin (1998). The physical location of different racialized groups was also an important factor in the 
whitening process. Jacobson $(1998$, p. 75$)$ notes: 'Thus in this period of volatile racial meanings, peoples such as Celts, Hebrews, Italians, and Slavs were becoming less and less white in debates over who should be allowed to disembark on American shores, and yet were becoming whiter and whiter in debates over who should be granted the full rights of citizenship'.

${ }^{4}$ Even as the number of lynchings declined, lynching stories worked to maintain the color line in the South. Hale (1998, p. 227) argues that '[T]he image of the "black beast rapist", providing a foundation for the culture of segregation beyond the reach of rational discussion, remained. The modern twentieth-century lynching had become the white South's own ritual of transgression, and by the late 1930s representations of lynching worked almost as well as lynchings themselves'.

${ }^{5}$ In New York City, the African American population nearly tripled between 1890 and 1910. By 1910, nearly 92,000 African Americans lived in the city and most of them were unmarried, Southern-born men. See Osofsky (1963, pp. 17-20). ${ }^{6}$ An article in Current Literature (Dec. 1909, p. 594) declared that the white slavery issue was 'so far transcending mere politics and so arresting in its national and international importance that it quickly overshadowed all the anticipated issues of the campaign, such as taxation, subways, and extravagance in expenditure'.

${ }^{7}$ Many regarded the commission of the Rockefeller grand jury as a trick by Tammany Hall designed to soothe the public without disturbing the city government's protection of vice. Rockefeller's biographer and confidante Raymond Fosdick suspected that Judge O'Sullivan's Tammany sympathies directed the particularities of the jury selection: 'perhaps as a method of clothing it with respectability he designated the younger Rockefeller to serve as its foreman' (Fosdick 1956, p. 137). 
${ }^{8}$ In a two hour interview with investigators, Levinson revealed the locations of three 'clearinghouses' or 'stockades' where 'they always have on hand an average of from five to eight women waiting to be transported to different points outside of New York City' (New York Daily Tribune May 5, 1910, p. 1). After his confession, detectives raided the buildings and found them deserted (New York Times May 6, 1910, p. 18). ${ }^{9}$ They charged her with violating section 2460 of the penal code: 'knowingly receiving money for and on account of procuring and placing women in the custody of another person for immoral purposes'.

${ }^{10}$ For an extended discussion of the role of the mulatto in nineteenth-century American literature in general and Uncle Tom's Cabin in particular, see Bentley (1993).

${ }^{11}$ Jewell (1993, p. 46) writes: 'Jezebel, more commonly known as the bad-black-girl, is a cultural image that is portrayed as a mulatto or fair-complexioned African American female, who possesses features that are considered European. Thin lips, long straight hair, slender nose, thin figure and fair complexion are the physical characteristics that make up this image.' Both African Americans and whites often associated light skinned mulattos with degradation and the sex trade (Davis 1991, p. 57).

${ }^{12}$ See Chauncey (1994). Chauncey (1994, p. 36) notes: 'Going slumming in the resorts of the Bowery and the Tenderloin was a popular activity among middle-class men (and even among some women), in part as a way to witness working-class "depravity" and to confirm their sense of superiority'.

${ }^{13}$ Ferber (1998, p. 30) notes a similar connection between race and masculinity in contemporary white supremacist discourse: 'Gender is often employed as an analogy for racial hierarchy where masculinity symbolizes white superiority, and the downfall of the race is described as a process of feminization'. 
${ }^{14}$ The historical importance of anti-prostitution efforts for the maintenance of racial boundaries should prompt speculation about the neo-colonial impulses in contemporary campaigns against the global trafficking in women and girls. Although this subject is beyond the scope of this article, it has already garnered the attention of other scholars. See Kempadoo (1998) and Doezema (2000).

${ }^{15}$ See Bederman (1995); Langum (1994); and Mumford (1997). Mumford writes (1997, p. 12) 'Throughout the Midwest and the North, despite the fact that only Indiana has passed a law prohibiting black/white intimate relations, black men and white women were stigmatized and often punished for engaging in interracial intimacy. Like Johnson, they were charged with either abduction or violation of the Mann Act'. 